\title{
Floods in East Siberia: damage and risks
}

\author{
L. M. Korytny \& N. V. Kichigina \\ V.B. Sochava Institute of Geography SB RAS, Irkutsk, Russia
}

\begin{abstract}
A notable area of research into floods involves geographical analysis of their occurrence and the factors that are responsible for them. We examine the main kinds of floods in East Siberia, their recurrence and distribution in the territory. Using archival, reference and published data, we made an analysis of the floods that occurred on this territory in the $19^{\text {th }}-20^{\text {th }}$ centuries. A zoning according to flood hazard is carried out. An analysis is made of the major floods in East Siberia which caused substantial damage during 1991-2006. The damage analysis showed that the most extensive damage in East Siberia is caused by snowmelt floods and ice-dam induced floods. For the Irkutsk region, risk severities and the damage caused by them were calculated, and the possibilities of the floods being linked with other hazards and their effects were explored.

Keywords: East Siberia, floods, regional analysis, zoning, risk, flood hazard, synergy effect.
\end{abstract}

\section{Introduction}

The regions of East Siberia, along with the North-Caucasian and Far-Eastern regions, are exposed the most to flood hazards when compared to the other areas in Russia. Floods in East Siberia are high on the list of natural disasters as regards their distribution and recurrence rate as well as the actual damage caused by them, and they are second only to earthquakes. Ninety percent of all residential centers and as much as $75 \%$ of arable lands and hayfields are concentrated here along the river valleys which have long been experiencing flooding events.

We have carried out a geographical analysis of the occurrence and causes of floods for the rivers of East Siberia. The analysis involved studying the flood genesis and recurrence rate on the basis of documented records as well as on data of instrumental observations on the rivers, assessing the flood hazard severity, 
zoning of the territory according to flood hazard, and evaluating the flood damage and risks.

\section{Causes of floods}

East Siberia is characterized by flooding events caused by spring (springautumn) snowmelt floods and summertime rainwater floods, by water level rises in the case of ice dams and ice jams, anthropogenic activity, specifically discharges of surplus amounts of water across the spillway of the integrated hydropower schemes, and by wind-induced pileups and rising tides in river estuaries. Water level rises on smaller rivers of East Siberia are frequently caused by melt water from naleds (aufeis) on these rivers. Every so often floods are caused by several factors simultaneously (as is the case with snowmelt and ice-dam floods on the foothills plain, and heavy rains in the mountains).

Ice jam is defined as choking of the open cross-sectional area of the river in the autumn-winter season at the freezing-up period by masses of frazil ice, slush ice, and debris of fast and small ice floes. Ice jamming is characteristic for segments with rapid turbulent flow where slush ice is generated on mountainous and semi-mountainous rivers. Ice dam is a clogging of the open cross-sectional area of the river channel at the period of break-up with drifting of ice that causes compression of the open cross-sectional area. Ice damming results in an intense rise in the water levels, both upstream and downstream, during break-up.

Snowmelt floods and rainfall floods are the commonest flood events in East Siberia. Analysis of the relationship between maximum water flow rates for these crucial hydrological phases reveals the following main regularities: the mountainous areas of the Western and Eastern Sayan, Khamar-Daban and of the North-Baikalian and Patoma highlands are dominated by rainfall flood maxima; on the Mid-Siberian tableland the largest water flow rates and levels correspond to the phase of spring or spring-summer snowmelt flooding; combinations of the causes are possible for the foothills plains. Snowmelt floods occur in May, while rainfall floods occur in July and, more rarely, in August. Combinations of rainfall floods with snowmelt flood runoffs (mixed floods) are relatively rare in occurrence.

Combinations of snowmelt floods with ice-dam floods are more frequent in occurrence, but it is not unusual to observe that ice-dams themselves cause floods. In East Siberia, the number of ice-dam floods and the damage caused by them are quite impressive, because the main East-Siberian rivers flow along a submeridional direction thus promoting ice-damming. Ice dams constitute up to one third or more of all the causes of floods. Thus, strong ice dams very long in size $(20-30 \mathrm{~km})$, causing extremely high water level rises $(8-10 \mathrm{~m})$, are formed on the Lena river due to a breakup delay in places of increased thickness and strength of ice cover where the stream channel is constrained by variously shaped islands differing in size. Noteworthy is also the fact that the Yana, Indigirka and Kolyma river basins are particularly prone to ice-dam floods (Table 1). A total of 447 ice-dam sections totaling $744 \mathrm{~km}$ in length can be 
Table 1: Characteristic of the segments of valleys prone to ice damming and ice-dam floods.

\begin{tabular}{|l|c|c|c|c|c|c|}
\hline Basin & $\begin{array}{c}\text { Ice-dam } \\
\text { sections }\end{array}$ & \multicolumn{5}{|c|}{ Ice-dam sections with floods } \\
\cline { 2 - 7 } & Number & $\begin{array}{c}\text { Length, } \\
\mathrm{km}\end{array}$ & $\begin{array}{c}\text { Numb } \\
\mathrm{er}\end{array}$ & $\begin{array}{c}\% \text { of total } \\
\text { number } \\
\text { of ice-dam } \\
\text { sections }\end{array}$ & $\begin{array}{c}\text { Length, } \\
\mathrm{km}\end{array}$ & $\begin{array}{c}\% \text { of total } \\
\text { length } \\
\text { of ice-dam } \\
\text { sections }\end{array}$ \\
\hline Yenisei & 175 & 2228 & 12 & 7 & 248 & 11 \\
\hline Angara & 42 & 271 & 8 & 19 & 54 & 20 \\
\hline $\begin{array}{l}\text { Lake } \\
\text { Baikal }\end{array}$ & 47 & 144 & 2 & 4 & 7 & 5 \\
\hline Lena & 133 & 3565 & 27 & 20 & 1684 & 47 \\
\hline $\begin{array}{l}\text { Yana, } \\
\text { Indigirka, } \\
\text { Kolyma }\end{array}$ & 50 & 1206 & 13 & 26 & 271 & 22 \\
\hline $\begin{array}{l}\text { East } \\
\text { Siberia }\end{array}$ & 447 & 7414 & 62 & 14 & 2264 & 30 \\
\hline
\end{tabular}

counted on the territory of East Siberia, and 62 of them (or 14\% of their total number) are the cause of floods.

Ice-jam floods occur more rarely. Before the construction of the hydroelectric power station, however, ice-jam floods often affected the city of Irkutsk. The largest number of ice-jam sections can be found in the basins of the Yenisei, Lake Baikal and the Upper Lena (upstream from its confluence with the Vitim).

Wind-induced water pileups occur in the zones within the mouths of the rivers in East Siberia. However, only rarely do the pileup events lead to large floods because these localities are sparsely populated and settlements and economic facilities are situated largely on elevated river banks. Smaller-scale pileup phenomena are characteristic for large lakes and reservoirs. On Baikal, for example, the level rise during pileup events is a high as 20-25 cm which occurs approximately every 15-20 years. The water level rise is still smaller during seiches (14-16 cm on Baikal). Pileups on the reservoirs of the Angara-Yenisei cascade can cause the water level to rise as much as $0.5 \mathrm{~m}$ or more. The risk of flooding of low river banks is quite real, even if relatively low.

Flood hazard as a consequence of the hydraulic-engineering construction is of the utmost significance. Thus, in recent years the head waters of the Angara cascade saw an increasingly frequent occurrence of water level rise above a normal backwater horizon, which was partly the cause of an almost constant flooding of the lower-lying areas of Baikal's shores. On the other hand, surplus water discharges across the dam for avoiding flooding in the upper pool leads to flooding and groundwater flood of the facilities downstream of the dam (as was the case in Irkutsk in 1995).

Particularly hazardous are the floods caused by failures to integrated hydropower schemes, with backwater forming break waves with huge volumes of water and very high speeds. It should be noted that the study region has several large hydroelectric power stations which are on the list of potentially 
hazardous economic facilities. A break of the dam of the Irkutsk hydroelectric power station would give rise to a zone of disastrous flooding affecting an area of $62.4 \mathrm{~km}^{2}$, with 123600 people finding themselves in the zone of potential flooding; for the Bratsk and Ust-Ilimsk hydroelectric power stations the figures are: $104 \mathrm{~km}^{2}$ (33 300 people) and $117 \mathrm{~km}^{2}$ (13 500 people), respectively. This hazard should be taken into consideration, also in view of the fact that a number of hydroelectric power stations are in the seismically hazardous zone.

\section{Historical overview of floods}

Even the first Siberian explorers, who settled along the banks of large rivers, had to struggle against floods. Floods are described in many historical documents and reference books. A unique summarization of the archival data on floods occurring on the rivers of the USSR for the documented period was carried out by Zaikov (e.g. Zaikov [1]).

A total of 106 descriptions of floods in East Siberia was reported by Zaikov for the documented period; among them, the proportion of snowmelt and rainfall floods is about the same (36 and $37 \%$, respectively), and the percentage of ice dam/ice jam floods constitutes $29 \%$ of the total number of floods recorded. Furthermore, three severe floods (class III) were recorded, with two of them caused by rainfall floods, and one caused by an ice dam on the Lena river. Flooding of residential centers was recorded in more than half of the events. The rivers of East Siberia showed the following regularity in the flood distribution: the Yenisei river basin was dominated by snowmelt floods $(68 \%)$ and ice-dam floods $(27 \%)$ while the basins of the Angara river and Lake Baikal were dominated by rainfall floods ( $80 \%$ and $67 \%$, respectively). Within the Lena river basin the largest number of floods was caused by ice dams, as many as $50 \%$ of the total number of the floods recorded.

Currently the most hazardous floods are those which are caused by water level rises at high rates due to rainfall within the basins of moderate-size rivers in the mountains and foothills areas. Such rainfall floods that are caused by rains lasting many days, and by continuous rains, often encompass extensive areas are widespread on many rivers in East Siberia. For instance, a disastrous flood occurred in August 1950 within the basins of the Kana, Mana and Biryusa rivers. In July 1971, in the Prebakalia and Trans-Baikalia, floods in the Irkutsk region alone affected 33 residential centers, 82 industrial enterprises, and about $700 \mathrm{~km}$ of motor roads. In July 1984, in the Tulun district (Irkutsk region), 12 residential centers were flooded within the Iya river basin, including one third of the area occupied by the city of Tulun, 5.5 thou ha of pastures, and 80 ha of croplands.

\section{Flood recurrence}

Our recurrence analysis used moderate, severe and disastrous floods. We used, as the numerical index of flood onset, a critical level, (Hcr.), at which the water occupies the floodplain resulting in a significant flooding of agricultural lands and, partly, residential centers, and this does correspond to a class of moderate 
floods. The values of critical levels, $(\mathrm{Hcr}$.) were taken from reference books: "Water Resources of the USSR".

The flood recurrence for the period of instrumental observations was calculated by the formula:

$$
p=(n / N) \times 100
$$

where $\mathrm{p}$ is recurrence, $\Pi$ is the number of years with an excess of Hcr, $\mathrm{N}$ is the total number of years of observation. All measuring sections were divided, according to the recurrence rate, into four groups with rare $(<30 \%)$ and frequent $(30-50 \%)$ floods, and with high $(51-70 \%)$ and very high $(>70 \%)$ recurrence (Table 3).

A total of 1703 floods were recorded at the measuring sections of the rivers in East Siberia for the period of instrumental observations (e.g. Korytny [2]). The Lena basin has the largest number of measuring sections with floods as well as the largest number of floods.

Table 2: Distribution of measuring sections on the basins according to the flood recurrence (numerator - number of measuring sections with floods, denominator $-\%$ of the total number of measuring sections with floods).

\begin{tabular}{|l|c|c|c|c|}
\hline \multicolumn{2}{|c|}{ Basins } & \multicolumn{4}{|c|}{ Flood recurrence, \% } \\
\cline { 2 - 5 } & $<30$ & $30-50$ & $51-70$ & $>70$ \\
\hline Yenisei & $11 / 40$ & $10 / 37$ & $5 / 19$ & $1 / 4$ \\
Angara & $2 / 22$ & $5 / 56$ & $-/-$ & $2 / 22$ \\
Lake Baikal & $3 / 38$ & $2 / 25$ & $1 / 12$ & $2 / 25$ \\
Lena, Yana, Indigirka & $18 / 42$ & $11 / 26$ & $7 / 16$ & $7 / 16$ \\
East Siberia & $34 / 39$ & $28 / 30$ & $13 / 15$ & $12 / 16$ \\
\hline
\end{tabular}

For nine measuring sections in different physical-geographical conditions of East Siberia we carried out an analysis of the indices of flood magnitude (impact). This characteristic combines several indices; it is very individual and is determined both by the hydrological conditions of floods and by the morphology of a river valley. It is showed that they differ greatly. The mean duration of floods fluctuates from 3 to 22 days. In most cases, the mean level rise above a critical level (Hcr.) exceeds $1 \mathrm{~m}$, and for the Lena at the city of Yakutsk it approaches $2 \mathrm{~m}$. A maximum rise of $5.5 \mathrm{~m}$ was recorded on the Iya river at the city of Tulun in 1984 .

Of special interest is the analysis of high floods, specifically with a level rise by $1.5 \mathrm{~m}$ above Hcr. Such floods are rather rare for many measuring sections, but for two sections (the Lena at the city of Yakutsk, and the Yana at the settlement of Dhzangty) they constitute more than half of the total number, which is accounted for by the ice-dam genesis of many of them. The mean duration of these floods fluctuates from 2 to 6 days. The longest-lasting snowmelt flood was recorded on the Yenisei river at the city of Yeniseisk. 


\section{Zoning of East Siberia according to flood hazard}

Integral flood hazard is determined by a combination of many factors (characteristics). We suggest that five hazard classes be identified by taking into account their genesis, recurrence, magnitude (impact) and damage as well as the possibility and advisability of forecasting them.

Class I (low hazard) includes situations either with constant small flooding (flooded meadows on the floodplain, etc.) or with a moderate, yet extremely rare, flood; forecasting is normally inexpedient. Class II of floods (moderate hazard) involves floods of moderate magnitude and damage, with relatively frequent recurrence; therefore, they are relatively easy to forecast. Class III (significant hazard) includes moderate and severe floods, with moderate recurrence, and with good predictability. Class IV (high hazard) incorporates all severe floods with rare recurrence; therefore, they are poorly predictable (this is especially true for snowmelt floods). And finally, class V (very high hazard) combines extremely rare and virtually unpredictable situations which can become the cause of disastrous floods; they include primarily floods occurring due to failures of the hydroelectric power stations' dams, and to other technogenic failures.

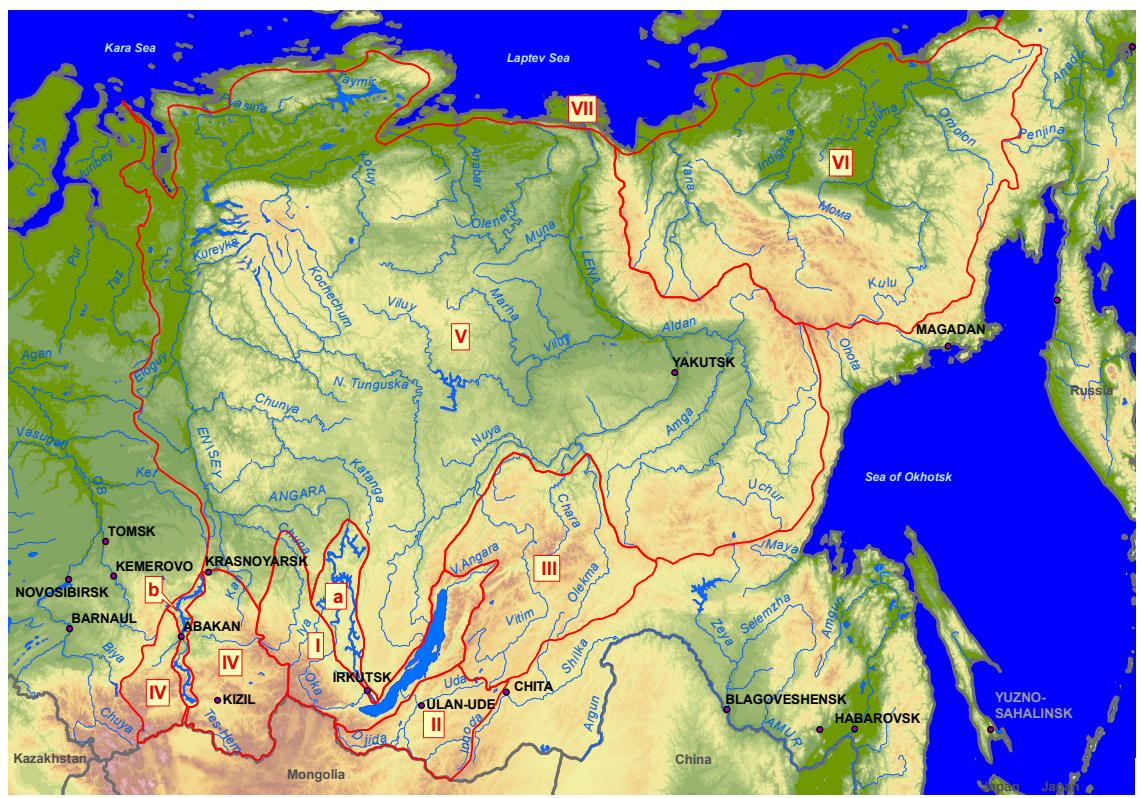

Figure 1: Regionalization of East Siberia according to flood hazard. Districts: I - Eastern-Sayan, II - Zabaikalsky, III - Vitim, IV - UpperYenisei, V - Mid-Siberian, VI - Northeastern, VII - NorthernSiberian; $\mathrm{a}$ and $\mathrm{b}$ - areas of hydrotechnical regulation. 
Finally, a micro-zoning of East Siberia was carried out according to flood hazard (Fig. 1, Table 5) (e.g. Korytny et al. [3]). The zoning effort took into consideration, in addition to hazard characteristics and their integral representation (hazard class), the physical-geographical differences between the regions, the predominant hydrologo-morphological parameters of the river valleys, and the level of their development and the density of population. As a result, a combination of all the characteristics being analyzed was used in identifying seven districts, or areas.

In addition to the aforementioned areas, particularly noteworthy are the areas of hydrotechnical regulation with increased flood hazard. They include shore areas of reservoirs with smaller tributaries as well as areas of potential flooding in the case of breakthrough floods downstream of the hydroelectric power stations. Such areas primarily include the shores of the reservoirs of the AngaraYenisei cascade as well as of the Vilyui and Khantai reservoirs. They represent special areas, because neither snowmelt floods nor rainfall floods were recorded on the regulated main rivers, but these territories are constantly threatened by breakthrough floods which were assigned hazard class V (the highest class).

Table 3: $\quad$ Flood hazard classes for the areas of East Siberia.

\begin{tabular}{|l|l|l|c|}
\hline No. & Name of district & \multicolumn{1}{|c|}{ Flood genesis } & $\begin{array}{c}\text { Flood hazard } \\
\text { class }\end{array}$ \\
\hline I & Eastern Sayan & Rainfall floods & III-IV \\
\hline II & Zabaikalsky & Rainfall floods & II-III \\
\hline III & Vitim-Olekma & $\begin{array}{l}\text { Rainfall, snowmelt, ice } \\
\text { dam/ice jam floods }\end{array}$ & II \\
\hline IV & Upper-Yenisei & $\begin{array}{l}\text { Snowmelt and rainfall } \\
\text { floods }\end{array}$ & II-III \\
\hline V & Mid-Siberian & $\begin{array}{l}\text { Snowmelt and } \\
\text { ice-dam floods }\end{array}$ & $\begin{array}{c}\text { I-II } \\
\text { III-IV }\end{array}$ \\
\hline VI & Northeastern & $\begin{array}{l}\text { Rainfall, ice-dam and } \\
\text { snowmelt floods }\end{array}$ & II-III \\
\hline VII & Northern-Siberian & $\begin{array}{l}\text { Snowmelt, wind- } \\
\text { induced and tidal floods }\end{array}$ & I-II \\
\hline
\end{tabular}

\section{Flood damage}

A total of 49 floods occurred in East Siberia during 1991-2006 which caused considerable material damage. Casualties were reported for five of them, and another five events required evacuation of people from the area of disaster. Those disastrous events were primarily caused by floods due to heavy rainfall as well as to long-lasting abundant rainfall (Fig. 2). 


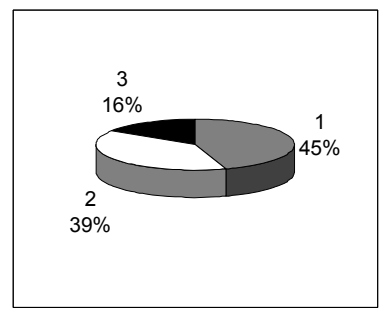

Figure 2: Proportion of the kinds of floods on the rivers of East Siberia during 1991-2006, \%, 1 - rainfall floods, 2 - ice-dam floods, 3 snowmelt floods.

The amount of material damage caused by large floods is quite considerable. Thus, for the aforementioned floods the damages were: about $\$ 48$ mil. in Buryatia in 1993; \$307 mil. In Yakutia in 1998, and \$8.6 mil. in the Irkutsk region in 2001 .

Flooding resulting from rainfall floods (about $50 \%$ of all floods) holds the lead as regards the damage caused in the East-Siberian economic area (without Yakutia), ice-dam floods rank next to it (30\%), and the third place is occupied by floods of a mixed origin (20\%) (e.g. Taratunin [4]). Furthermore, the damage is distributed in the sectors of the economy as follows. The greatest damage is caused to agriculture, and to municipal facilities: 28 and $30 \%$ of the total damage, respectively; next comes the damage caused to the transport: $19 \%$, and to the industries: $16 \%$, and finally, the damage to personal property is estimated at about $7 \%$. These figures vary in different regions of East Siberia and are dependent on the level of development of the particular economic sectors in them.

\section{Flood risk evaluation}

Flood risk evaluation implies calculating the probability of an event, including determination of the boundary conditions for its preparation, development and manifestation. We carried out a risk analysis for the territory of the Irkutsk region, based on actual statistical data spanning the period from 1999 through 2004. As the initial indices, we used the amount of damage, and the flood frequency (recurrence).

The territorial cell was represented by an intra-regional administrative district. In this case the risk $R_{i}$ is used in reference to the product of the number of events $n$ by the ratio of specific damage $D$ (equal to the ratio of the sum of all damage of a given kind of hazard of the region in the monetary form to the number of districts) to the sum of all damage of a district from a given kind of hazard $U_{i}$ (e.g. Akimov and Radayev [5]):

$$
R_{i}=n *\left(D, \Sigma U_{i}\right) * 100 \%
$$


The calculated risk values are categorized according to three classes, with the rank determined by the expert estimate method corresponding to each of them. In this case, classes 1.2 and 3 correspond, respectively, to increased hazard level (rank 1), threatening hazard level (rank 2), and to alarming hazard level (rank 3). An exponential distribution of risks is assumed in the ranking process. Risk indices are indicated along the exponential axis, and the abscissa axis is divided into three equal intervals within the corresponding data (e.g. Korytny et al. [6]). Results of calculations for one of the east-Siberian districts (Irkutsk region) are provided in Table 4 .

Table 4: Risk calculation and flood hazard ranking for the districts of the Irkutsk region.

\begin{tabular}{|l|c|c|c|c|}
\hline District & $\begin{array}{c}\text { Damage } \\
\text { (\$ US) }\end{array}$ & Recurrence & Risk, \% & Rank \\
\hline Angarsk & 177400 & 1 & 2.065 & 1 \\
\hline Zhigalovo & 46667 & 1 & 0.543 & 1 \\
\hline Zalari & 1218333 & 1 & 14.180 & 2 \\
\hline Katanga & 430966 & 5 & 5.016 & 1 \\
\hline Usolsky & 546767 & 1 & 6.364 & 1 \\
\hline Ust-Kut & 3170067 & 1 & 36.895 & 3 \\
\hline Cheremkhovo & 844167 & 1 & 9.825 & 1 \\
\hline Irkutsk & 112433 & 1 & 1.309 & 1 \\
\hline Zima & 1777733 & 2 & 20.690 & 2 \\
\hline
\end{tabular}

\section{On the synergy effect}

In the case of a correlative treatment of hazard ranks of different kinds, both natural and technogenic, a synergy combination is possible, where the hazards start to interplay with each other thus acquiring new qualities and development mechanisms and becoming largely devoid of the amount of overall risk. For the individual areas on the territory of the Irkutsk region we determined consistent combinations of different hazards. Specifically we identified two kinds of characteristic integration of floods with other hazardous events which form composite cascade-like emergency situations (ES).

1. A correlation of flood hazard with high breakdown rate at production plants. This type of hazard is typical of the Angarsk, Irkutsk and Usolsky districts. In this case, a natural ES is responsible for breakdowns in the production sphere.

2. A correlation of floods with high transport accident rate. It is typical of the Usolsky and Ust-Kut districts. Such a correlation is hazardous primarily for hydropower schemes, as they are damaged the most when situations of this kind occur. 


\section{Conclusion}

The research results presented make it possible to define the rainfall floods and ice-dam floods in East Siberia as causing the greatest damage. Each of the seven areas that have been identified according to flood hazard has a specific set of genetic kinds of floods. Geographical analysis of the flood distribution and the associated factors that are responsible for flood events, combined with risk calculations, offers new possibilities of developing targeted measures for flood forecasting and control.

\section{Acknowledgements}

We are grateful to Jennifer Sutton and V. Mikhalkovsky for their assistance in preparing the final English version of the manuscript.

\section{References}

[1] Zaikov V.D. High Snowmelt and Rainfall Floods on the Rivers of the USSR for the Documented Period: Leningrad: Gidrometeoizdat, 135 p., 1954.

[2] Korytny L.M. and Kichigina N.V. Floods along the river valleys of East Siberia. Vodnye resursy, 2: pp. 161-165, 1998.

[3] Korytny L.M., Gartsman B.I., Kichigina N.V., and Gubareva T.S. Rain Floods of the Far East and East Siberia. In: Extreme Hydrological Events: New Conception for Security. Springer, pp. 125-135, 2007.

[4] Taratunin A.A., Floods on the Territory of the Russian Federation. Yekaterinburg: Russian Research Institute of Integral Utilization and Protection of Natural Resources, 375 p., 2000.

[5] Akimov A.A. and Radayev A.N. Natural and Technogenic Hazards: Risk, Monitoring, Forecasting. Moscow, 2004.

[6] Korytny L.M., Kichigina N.B. and CherkashinV.A. Floods and Their Risk Assessment in Southern East Siberia In: Series: NATO Science for Peace: C - Environmental Security: Threats to Global Water Security (edited by J. Anthony A. Jones, Trahel G. Vardanian, and Christina Hakopian), Springer Science + Business Media B.V., pp.247-252, 2009. 